\title{
Despair and Disillusionment in Post-Negritude African Literature
}

\author{
Sunday Tasen Okune ${ }^{1}$, Alexander Essien Timothy ${ }^{2, *}$ \\ ${ }^{1}$ Department of English and Literary Studies, University of Calabar, Calabar, Nigeria \\ ${ }^{2}$ Department of Arts Education, University of Calabar, Calabar, Nigeria \\ Email address: \\ drstokune@yahoo.com (S. T. Okune),profalext@gmail.com (A. E. Timothy) \\ ${ }^{*}$ Corresponding author
}

\section{To cite this article:}

Sunday Tasen Okune, Alexander Essien Timothy. Despair and Disillusionment in Post-Negritude African Literature. English Language, Literature \& Culture. Vol. 2, No. 5, 2017, pp. 45-51. doi: 10.11648/j.ellc.20170205.11

Received: November 11, 2016; Accepted: December 23, 2016; Published: October 3, 2017

\begin{abstract}
In their spirited and desperate bid to correct the distorted notion of Africa held by some European ethnologists, Negritudian writers such as Leopold Senghor, Leon Damas, Aime Cessaire, Gilbert Gratiant, Leonard Sainville, etc tended to portray Africa and the black world in rather glowing terms of beauty and idealism. Despite the robust hope and idealism echoed in Negritude literature about Africa, the reality of life in post-Negritude paints a dismal picture of despair and disillusionment. This paper explores how some African writers of the post-Negritude era have committed their art to the exploration of such related themes of despair, disillusionment, corruption, brutality, conflicts, etc, that are quite contrary to the idyllic picture painted by the founding fathers of Negritude.
\end{abstract}

Keywords: Negritude, Disillusionment, Literature, Corruption, Hope

\section{Introduction}

Hope and aspiration are the dynamics of the human species. When a people are devoid of hope and aspiration, they sink into the abyss of developmental atrophy. It is often the case that when a people are under oppression, they usually dream about an ideal situation that may or may not materialize someday. They hope for and sing about a glowing future time when freedom shall be realized. During Africa's colonial era, the continent was subjected to the yoke of the colonial masters who exploited her human and rich natural resources. But long before the colonial era, Africa's past in the pre-colonial time was less than ideal. Millions of African young men and women were abducted and sold into slavery in Europe and in the New World.

During the dying days of colonialism, Africa experienced a tidal wave of nationalistic fervor in her struggle to overthrow the yoke of colonial contraption. One of the protest movements was galvanized around a budding literary and cultural renaissance called Negritude, initiated by Francophone African students who were studying in France in the 1930's. The apostles of this movement were Leopold Senghor, Leon Damas and Aime Cessaire. Negritude became a rallying point for these black students in France to protest against the racial stereotype of Africans spawned by some European ethnologists. It was not unusual that Negritude was characterized by a glowing depiction of Africa and a celebration of Africa's pre-colonial era.

Some critics have described Negritude literature as being sentimental and unrealistic in its depiction of Africa's glorious past and celebration of blackness. Of course, the themes and style of Negritude literature were to be expected because the Negritude writers were too passionately involved in their debunking of the negative and demeaning characterization of Africa by western ethnologists that they sounded sentimental and strident. Despite these weaknesses in the Negritude movement, it can be argued that the movement saw the emergence of a vibrant literary voice from Africa, whether at home or in the diaspora.

Then came the post-colonial era on the African continent with its initial robust hope and idealism. Some five decades after independence in most African nations, how well has Africa fared in her developmental stride? If the independence of African nations was greeted with hearty and euphoric optimism as to the future prospects of these fledgling nations, a few decades in the post-independence era has left Africans 
more disillusioned about the capacity of Africa to manage her vast human and material resources. Often, blames are apportioned to Africa's colonial and neo-colonial heritage as being the cause of the continent's underdevelopment. But while it may be argued that Africa's colonial and neocolonial heritage have played a role in the continent's underdevelopment, it can also be argued that Africa cannot solely blame her economic and political woes on her colonial and neo-colonial legacies. This paper, therefore, examines the contrary argument of the post-negritude writers as they exploit the themes of corruption, underdevelopment, illiteracy, and so on.

Negritude writers like Aime Cesaire took pride in the fact that African values are original and in close proximity to the world of spirit through nature, as opposed to the artificial materialistic values of the west. Cesaire rejects the materialistic values of the west as part of his protests and asserts that:

My negritude is not a stone with its deafness hurled against the clamour of the day. My negritude is not a speck of dead water on the dead eye of the earth. My negritude is neither a tower nor a cathedral. It plunges into the red flesh of the ground. It plunges into the ardent flesh of the sky pierces through the opaque despondency by its straight patience.(Return to My Native Land Cesaire qtd. in Okeh 2000, 153).

Jonna Roger's view captures the thought raised above in asserting that the basic ideas behind Negritude is predicated on the assumption that:

The mystic warmth of African life, gaining strength from its closeness to nature and its constant contact with ancestors, should be continually placed in proper perspective against the soullessness and materialism of western culture; that Africans must look to richness of their past and of their cultural heritage in order to choose which values and traditions could be most useful to the modern world....(2009, 1).

Next, we should consider one of David Diop's finest poems by the title of "Africa" and see how the poet was able to explore the three eras of Africa's socio-political evolution:

Africa

\section{Africa my Africa}

Africa of proud warriors in ancestral savannahs Africa of whom my grandmother sings

On the banks of the distant river

I have never known you

But your blood flows in my veins

Your beautiful black blood that irrigates the fields

The blood of your sweat

The sweat of your work

The work of your slavery

The slavery of your children

Africa tell me Africa

Is this your back that is bent

This back that breaks under the weight of humiliation

This back trembling with red scars

And saying yes to the whip under the midday sun

But a grave voice answers me
Impetuous child that tree young and strong

That tree over there

Splendidly alone amidst white and faded flowers

That is your Africa springing up anew

Springing up patiently obstinately

Whose fruit bit by bit acquire

The bitter taste of liberty. (qtd. in Senanu \& Vincent 1981, 68).

The above poem by David Diop highlights three historical periods in Africa's historical/ political experience: the precolonial period of heroic past with great warriors, the colonial period of subjugation, suffering, exploitation, humiliation, and the post-colonial period that saw African nations asserting their independence and nationhood. The tone of the poem is nostalgic, particularly the first seven lines that extols Africa's past. Though Diop knew little about Africa, yet the "beautiful black blood" of Africa "that irrigates the fields" flowed in his veins. Negritude poets were sometimes excessive in their praise of Africa. In commenting on this theme, Nwoga opines that:

"Africa of proud warriors in the ancestral savannahs" does not give a complete contemporary view of Africa. It is as if the poet had to go back to the past to find something to be proud of in Africa $(2001,235)$.

\section{The Curse of Africa's Underdevelopment}

Adekunle Olowonmi (2008) has submitted that the African writers have committed their arts to $\mathrm{x}$-raying the social anomalies of their time.

With reference to African literature, Olowonmi notes, "Now, it is being employed as virus-resistant software; reflecting and refracting postcolonial disillusionment. Thus, African literature becomes an encyclopedic containment of the experiences of the people of the continent." Despite the glowing talks about Africa's glorious past, the reality of life for the people of the continent remains a miserable one. Some African writers such as Chinua Achebe, Wole Soyinka, Ayi Kwei Armah, Christopher Okigbo, Gabriel Okara, etc., have been able to capture the themes of political corruption, civil strife, despair and disillusionment in post independence Africa in their works. There are several factors that account for Africa's underdevelopment. The burden of change for the better, given these factors, rests squarely on the shoulders of the leadership of various African nations, including the citizenry. The basic factors that are responsible for the poor state of development on the continent are discussed in this paper.

\subsection{Political Instability}

Political instability is one of the reasons for Africa's underdevelopment. No sooner did most African nations become independent than coups and counter coups begin to become a common feature of the political landscape of the continent. Military coup in the Democratic Republic of 
Congo (then Zaire) led to the assassination of Patrice Lumumba, the nation's first Prime Minister after independence. One of the key actors in the coup, Mobutu Sese Seko, mounted the seat of power (1965-1997) and corruptly enriched himself and his cronies from the nation's rich diamond mines.

Military coup in Nigeria (Africa's largest nation) in the mid 1960's led to four years of bloody civil war in which over a million lives were lost. Since then, the nation's development has been stymied by both corrupt military and civilian leadership, leading to the impoverishment of the citizenry of the oil-rich West African nation. Other nations like Mozambique, Rwanda, Sierra Leone, Somalia, Sudan, Uganda, Angola, Burundi, Chad, Congo DR, Ethiopia, Liberia, etc., have all experienced post-independence political instability in one form or another, which tended to slow down development.

Chinua Achebe observes the rabid corruption and political instability characterized some post-independent African states in his novel $A$ Man of the People. The political elites had suddenly become greedy and corrupt in their new offices. Drunk by power, they became excessive and abusive in their use of power, such abuses people usually associate with military dictatorship. Politicians such as Chief M. A. Nanga, MP, epitomized the decay of the political elite in postindependence era in Nigeria. Elections were characterized by massive rigging and violence, giving rise to an overthrow of the government by the military who themselves were hungry for a taste of power. Published in 1966, A Man of the People was, indeed, prophetic about the direction of events in Nigeria at the time. For this reason, Achebe was accused of complicity in the nation's first military coup of 1966.

Corruption, which remains the greatest challenge to the continent development, may also be traceable to leadership style in most African nations. Leaders often rule their countries as though they were private estates. Political office becomes a means of personal aggrandizement. Leonard and Straus in Africa's Stalled Development observe this about the "personal rule paradigm":

Corruption is related to patronage politics. A key feature of patrimonialism is that public office is treated as personal property. In such a case, a public office becomes a means for extracting private wealth, which is essentially another way of describing corruption. Stealing money is probably not the common form of corruption in a personal rule system, even though that may be the first image that leaps to mind. Rather, corruption more frequently takes the form of using public office with the intention of building private power and accumulating private capital, whether through business deals, property purchases, concessionary taxes, or other means of manipulating public office for personal gain (2003, 2-3).

The Ghanaian author, Ayi Kwei Armah, is one of those African writers whose work explores the post-independence African experience. The central theme of The Beautiful Ones Are Not Yet Born is on the post-independence era of corruption that the young nation of Ghana in West Africa experienced. The story centres on an unnamed lonely rail worker who is pressurized by his family members and fellow workers to accept bribes and engage in shoddy practices in order to provide for his family materially. The moral stench emanating from social corruption is graphically captured in fecal terms that littered a public rest-room. But for good reasons the author does not name the protagonist of the novel, who is called The Man. Presumably, The Man would refer to every Ghanaian citizen who tries to lead a life of moral rectitude in a morally corrupt society.

\subsection{Ethnicity and Civil Conflict}

Another scourge on the continent's development is the issue of ethnicity and civil conflicts. Ethnicity is a strong factor in Africa's politics. Most of the wars fought in different countries on the continent emanate from ethnicity factor and local politics. Some of these ethnic conflicts snowballed into full scale civil conflicts that have claimed so many lives and destroyed property that run's into billions of dollars. The world was stunned at the scale of blood-letting in the Rwandan crisis of the '90s between Hutsus and the Tutsis. Often, civil conflicts arise in attempt by one ethnic group to gain control of the nation's mineral resources. For example, the Biafran secession bid led to the Nigerian civil wars of the mid 1960's to the late 1960's, in which over a million lives were lost. Within the past two to three decades, similar conflicts have rocked Liberia, Sierra-Leone, Ivory Coast, the Congo DR and elsewhere on the continent that have tended to slow down the pace of development. Again, Leonard and Straus in their observation posit that:

Almost all civil conflict in Africa is enmeshed in local politics. The key actor who prosecute civil conflicts all fight for something, whether that goal be political power, control of lucrative economic markets, or defeat of a rival. To gain legitimacy for their cause or to win recruits, the elites who promote civil conflict often justify their cause as part of a grander scheme. Fighting in the name of a community is one way to gain support and to situate one's cause in a nobler framework - on behalf of one's own $(2003,58)$.

The Nigerian poet, Gabriel Imomotime Okara, in his poem "Suddenly the Air Cracks" captures the violence and ravages of the Nigerian Civil War in the following lines:

Suddenly the Air Cracks

Suddenly the air cracks

with striking cracking rockets

guffaw of bofors stuttering LMGs

Jets diving shooting glasses dropping

breaking from lips people diving

under beds nothing bullets flashing fire

striking writhing bodies and walls -....

And the curling black smoke,

the sadless hearts and the mangled

bodies stacked in the morgue

become memorials of this day (qtd. in Senanu \& Vincent 1981, 51).

The onomatopoeic quality of the poem, coupled with the absence of internal punctuations in the first stanza, are employed to achieve specific type of rhythm and to capture 
the tensed moment brought about by the outbreak of war.

Another Nigerian poet, Titus C. Nwosu, in his poem "Star Dust" also depicts the futility of the wanton destruction and blood-letting caused, not by the angry gods, but by angry humans, the harvest of which is death and lasting sorrow:

Star Dust

Harvest is no blessing

When death is the crop

He was both the crop and the harvest

The plough - man and the ploughshare

The bowie-knife and the handle

That cut and was cut both ways!

No the gods are not angry, we are;

For these dark rain - clouds

That now hang over our eyes

Will eat through to our hearts

And make a bitter cold of lasting sorrow

(In Senanu \& Vincent 1981, 165).

For his part, Christopher Okigbo, a Nigerian poet who was killed during the Biafran War in October 1967, predicted the Nigerian Civil War in his collection of poems Path of Thunder composed in 1966. He died on the Nsukka battle front while fighting on the side of Biafra, but not until he had penned the following lines and others that depicted the poet's feeling of uncertainty and premonition on the state of the Nigerian nation in the new era of a "miracle of thunder":

The elephant, tetrarch of the jungle

With a wave of the hand

He could pull four trees to the ground;

His four mortars legs pounded the earth:

Wherever they treaded,

The grass was forbidden to be there

("Hurrah for Thunder" Okigbo 1971, 77)

The elephant, tetrarch of the jungle, may very well refer to the potentially volatile state the nation was then facing. Indeed, the elephant was let loose with destruction and violence following in its trail. Even the poet himself became a victim of the elephant's rage.

\subsection{Incompetent Leadership/Debt Burden}

Incompetence of the leadership in most of the countries that make up the continent remains the greatest challenge to the development of Africa. No nation can rise above the moral complexion of its leadership. To put it in an unvarnished language, the leaders of most African nations are nothing but thieves in the guise of honorable men and women. They are leeches who are sucking the life - blood out of their hapless victims - the citizenry. The collective impoverishment of Africa is a plague induced by the lousy, corrupt, irresponsible and incompetent leadership. In a continent where more than $70 \%$ of the populace live below the poverty line, the hope for development becomes nothing but a pipe dream.

The wealth of most post-independent African nations is squandered by leadership. Billions of dollars of national wealth is ruthlessly looted and stashed in banks overseas by
Africa's unscrupulous leaders. Given this scenario, we may very well admit that even the problem of Africa's huge debt burden is caused by the continent's inept and dishonest leadership who borrow huge sums of money from such foreign institutions like the IMF and World Bank, ostensibly for national development when, actually such monies usually end up in private account overseas. This situation does not augur well for Africa's development.

Such leaderships in Africa are not only incompetent and corrupt; they are lacking in vision and patriotism. Clearly, most of these leaders do not have the interest of their countries at heart. Their pre-occupation is in lining up their pockets with loots. Thus, the masses of Africa are now worse for it being governed by their own people than they were under colonial masters. There is no doubt that the western nations also have a share of the blame in Africa's underdevelopment, but our submission is to the effect that Africa's backwardness in the post-independence era is to be blamed more on the kind of leadership that have emerged from the continent. And for a long time to come, WE do not see any remarkable change in the outlook of things on the African continent vis-à-vis development. The so-called democratic institutions in most of Africa are actually, kleptocracy in disguise. Tim Harford in The Undercover Economist quotes Mancur Olson as indicating that "Kleptocracy at the top stunts the growth of poor countries" (2007, 185). This could not be truer in the case of African countries.

Based on the aforementioned, it may be argued that there is a correlation between incompetence and corruption of African leadership on the one hand, and debt burden plaguing most countries on the continent on the other hand. Africa becomes a beneficiary of hand - outs and other aids package from the western nations, which often do not accomplish much in alleviating the continent's poverty situation because of corruption and fiscal recklessness on the part of the leadership of various African countries.

In his book From Feast to Famine Bill Rau posits that the Compact for African Development document sought to clarify the causes of the development and food crises in Africa, a situation described as bleak. While suggesting that financial and technical contributors are "well - intentioned", the document also indicates that Africans are "unwise" and "wasteful", pointing out that corruption among national elites has drained national resources $(1991,113)$.

\subsection{Lack of a Solid Technological Base}

As discussed above, most economies of African nations rely heavily on agriculture or mineral resources. Most African nations lack a solid industrial and technological base to facilitate and sustain economic growth and development. Thus, while most African nations supply the necessary raw materials that feed industries in western nations, African nations largely have maintained the status of consumer nations. Even with economies that are mainly agro-based, most agricultural practices in Africa are still primitive and manually based. While the western nations employ 
mechanized farming system, Africa and most third world nations still rely on manual labor, with the resultant poor output. Walter Rodney's views reveal that:

The countries of Africa, Asia, and Latin America are called agricultural because they rely on agriculture and have little or no industry; but their agriculture is unscientific and the yields are far less than those of the developed countries $(1982,16)$.

Perhaps, for a long time to come, African nations would remain largely consumer nations, relying on and enjoying the benefits of imported technology from the more fortunate west. Similarly, Frantz Fanon notes the following regarding Africa's status as typically that of producers of raw materials:

Independence does not bring a change of direction. The same old groundnut harvest, cocoa harvest, and olive harvest. Likewise, the traffic of commodities goes unchanged. No industry is established in the country. We continue to ship raw materials, we continue to grow produce for Europe and pass for specialists of unfinished products $(1963,100)$.

\subsection{Lack of Infrastructural Facilities}

Coupled with the problem of the lack of a solid industrial base to facilitate development in Africa, is the challenge of a dismal lack of infrastructural facilities such as good access road network linking cities and rural-urban areas of the continent, electricity, internet, pipe-borne water supply, effective communication system, effective transportation system, efficient health system, etc. Without these basic facilities, economic development would be stalled. Though in recent years (within the last decade), there has been a tremendous growth in the telecommunication revolution sweeping across Africa, yet only a handful can afford the communication gadget. Besides, communication facility is just an aspect of the overall infrastructure. When these facilities are lacking, there is little or nothing that can be accomplished as far as development is concerned in Africa.

To a large extent, the inability of most African nations to provide adequate infrastructural facilities lies with corruption and lack of political will by the ruling elite. In a continent where the "theory of government banditry," according to Tim Harford, the undercover economist, is the maxim, there is bound to be a miserable lack of a secured environment for investment opportunities. The government does not encourage it either, since most African governments do not have the interest and welfare of their people at heart.

\subsection{Dictatorship}

From colonialism to home - grown dictatorship - this is the experience that defines most post-independent African states. It makes no difference whether the regime is a military regime or the ostensible democratic regimes, the fact remains that in the African experience, it is merely a change of garb, with no change in administration style. And nothing more than dehumanizes a people than dictatorship or a totalitarian regime. When a people have no say in determining how they are governed and who governs them true, progress and development that begin with the individual are often stalled.
Most African states had/have been accursed with dictatorial and totalitarian regimes in one shade or another. Some are familiar with such names as Idi Amin, Mobotu Sese Seko, Col. Mengitsu Haile Mariam of Ethiopia, Oma Bongo, Eyasingbe Eyadema, General Ibrahim Babangida, General Sani Abacha, Paul Biya, Robert Mugabe, Sgt. Samuel Doe, Paul Kagame of Rwanda, Yoweri Museveni of Uganda, Teodoro Obiang of Equatorial Guinea, Jean-Bedel Bokassa, Charles Taylor, Omar Al-Bashir of Sudan, Muammar Gaddafi of Libya, etc, who had/have both corruptly enriched themselves and oppressed their people, allowing them little or no freedom to protest against the highhanded regimes.

Wole Soyinka's The Man Died contains his prison memoir during his incarceration in 1967 by the dictatorial military regime of General Yakubu Gowon. Soyinka's crime was his effort at brokering a peace deal between the Federal Government and the secessionist Biafran side during the Nigeria Civil War. The dictatorial military regime of Gowon was known for its gross human right abuses. Those who dared to speak out against the oppressive regime were hunted down and brutalized. Human worth and dignity are eroded during such dictatorial regimes. For this reason "The Man Dies in all who keep silent in the face of tyranny".

\subsection{High Rate of Illiteracy, Poverty and Disease}

Illiteracy, poverty and disease are three interrelated factors that plague Africa's developmental bid. A well trained and an enlightened population can contribute more to national development than an unenlightened one. The high rate of poverty in Africa means that only very few can afford the cost of a good education. Equally true is the fact that an enlightened population may not only afford the means for healthcare cost, but may also acquire the basic health education necessary to main better health. Besides, a sick and depleted labor force would be a minus for Africa's economy. Africa suffers the highest death rate due to malaria, HIV pandemic, cholera, malnutrition, etc., traceable to a high rate of illiteracy, poverty, and lack of an efficient health delivery system.

Ositadimma Ejelike's article "How Corruption Underdeveloped Africa" raises some very crucial issues regarding Africa's underdevelopment. He observes that despite the abundant mineral and human resources, millions of Africans live below the $\$ 1.25$ a day World Bank poverty line, being deprived of basic social amenities. Ejelike links corruption to Africa's several woes such as increase in the cost of doing business on the continent, creation of yawning gap between the rich and the poor, underdevelopment, civil wars, ethnic tensions, poverty, and various crimes affecting the citizenry. He equally indicts western countries as playing a key role in encouraging corruption amongst Africa's ruling elites, in that yearly billions of dollars looted from national treasuries are stashed away in foreign western banks, who in turn make huge profits from these illicit monies. These loots also contribute to the development of western economies, while Africa remains economically underdeveloped. 


\section{Conclusion}

As a literary/cultural renaissance, Negritude literature has its place in the literary experimentation of Black African writing. Despite the glowing picture painted about Africa's past by the Negritude writers, the reality of things on the African continent is less than ideal. Though much blame for Africa's underdevelopment has been put on the western powers, it is high time the African leadership and its people took a look inward and see how they can forge a better future for the people of the continent. Leadership of the various African countries must be responsible in their governing and accountable to the people over whom they govern.

African nations, just like other poor third world nations, have been recipients of the benevolence of the western nations. There have been dissenting voices regarding providing lasting solutions to Africa's economic woes. While some speak in favor of the benevolent gestures such as handouts and debt cancellation from their creditors, others oppose any such gestures, on the grounds that such foreign aids do little or nothing in alleviating Africa's economic woes. Debt cancellation and foreign aids to African nations would be beneficial only if there is a high level of accountability on the part of the recipient nations. But in the absence of such accountability and proper monitoring, such foreign aids usually end up in private accounts of the leadership and their cronies, thus defeating the intended purpose of the handouts.

Dorothy Logie and Michael Rowson are of the view that if properly managed, debt relief could help in alleviating poverty and in promoting health. On the contrary, Robert Snyder avers that debt cancellation will work only if the factors that created debt in the first instance are effectively addressed, citing a case study of Rwanda to "demonstrate why political and social change must occur for debt forgiveness to work" $(2009,275)$.

Again, African nations must be able to manage their resources and stop looking to the west for aid. We could not agree more with Leonard and Straus who argue that extreme dependence on overseas aid by African countries results in "African elites - political, economic, and social - [becoming] externally oriented and insufficiently focused on the domestic opportunities that would produce sustainable development". While advocating the cancellation of all debt, they at the same time call for the reduction of aid so that African nations may assume "the initiative for Africa's development "(2003, x).

Meantime, while pointing out the dangers of protest literature as that of misjudging European culture, Nwoga expresses the fear that in their exile and in their attempt to present the picture of an oppressed Africa, the Negritude poet would exaggerate the grandeur or innocence of Africa, or dwell so long in Africa's past while ignoring to address those problems plaguing the continent in the post-independence era (2001, 217). Indeed, the paradox of Africa's political struggle is that while the nationalists fought hard to free their people from the yoke of colonial domination, post-independence Africa largely remains a backward continent engrossed in the mire of corruption, ethnic rivalry/civil strife, political instability and nauseating poverty, which are self-inflicted.

Some African writers have diverged from the glorification of Africa in view of the stark reality of corruption, poverty, disease, and political instability. Those writers have employed their creative arts to draw "...from the pool of experiences..." to interpret, recreate reflect or refract, (Dasylva 2003, 201) on the reality of despair and disillusionment that populate their experiences. So long as the conditions that instigated the gloomy rhetoric of these authors persist, their literature remain fervent alarm that must be heeded if Africa should migrate from the mire of perpetual penury and backwardness to the pedestal of prosperity and development. The counterpoint to this disillusionment is possible if African nations - both leadership and citizenry alike - forge a new path of harmony, transparency, patriotism, and mutual prosperity.

\section{References}

[1] Achebe, Chinua. A Man of the People. New York: Anchor Books, 1967.

[2] Angrey, Francis. "The Major Themes of Negritude Poetry: Protest, Revolt and Reconciliation" Introduction to Francophone African Literature: A Collection of Essays. Eds. Olusola Oke and Sam Ade Ojo. Ibadan: Spectrum Books, 2000 (89-97).

[3] Armah, Ayi Kwei. The Beautyful Ones Are Not Yet Born. Boston: Houghton Mifflin, 1968.

[4] Dasylva, A. O. (2003): "The Writer and Ph(f)aces of Conflicts in African" in Oyeleke Lekan and Olateju Moji (ed) 2003: Readings in Language and Literature. Nigeria: O. A. U. Press Ltd.

[5] Ejelike, Ositadimma. "How Corruption Underdeveloped Africa" in The Guardian - Nigeria. Wednesday, February 23, $2011<$ http://odili.net/news/source/2011/feb/23/13.html/>.

[6] Fanon, Frantz. The Wretched of the Earth. (Trans.) Richard Philcox. New York: Grove Press, 1963.

[7] Harford, Tim. The Undercover Economist. New York: Random House, 2007

[8] Leonard, David K. \& Scott Straus. Africa's Stalled Development: International Causes and Cures. London: Lynme Rienner, 2003.

[9] Logie, Dorathy, Micheal Rowson \& Robert Snyder. "Should Developed Countries Provide Debt Relief to the Poorest Indebted African Nations?" Taking Sides: Clashing Views on African Issues ( $3^{\text {rd }}$ ed.). Ed. William G. Moseley. New York: Mc Graw Hill, 2009: 275-276.

[10] Monkwenye, Cyril. "Senghor as Pre-Independence Negritude Poet". Themes in African Literature in French: A collection of Essays. Eds. Sam Ade Ojo and Olusola Oke. Ibadan: Spectrum Books, 2000: 3-14.

[11] Nwoga, Donatus I. West African Verse: An Anthology. Harlow Essex, UK: Longman, 2001.

[12] Nwosu, Titus C. "Star Dust". A Selection of African Poetry. Eds. K. E. Senanu \& T. Vincent. Essex: Longman, 1981: 165. 
[13] Okara, Gabriel I. "Suddenly the Air Cracks". A Selection of African Poetry. Eds. K. E. Senanu \& T. Vincent. Essex: Longman, 1981: 51.

[14] Okeh, Peter I. "Negritude and the Issue of Identify in African Literature." Major Themes in African Literature. Ed. Damian U. Opata \& Aloysius U. Ohaegbu. Nsukka: AP Express, 2000: 147-161.

[15] Oke, Olusola. "Modern African Literature as Illusions of Africa Reality: The Case of the Francophone Novel". Introduction to Francophone African Literature: A Collection of Essays. Eds. Olusola Oke \& Sam Ade Ojo. Ibadan: Spectrum Books, 2000: 218-222.

[16] Okigo, Christopher. Labyrinths and Path of Thunder: Poetry by Christopher Okigbo. Trenton, NJ: Africa World Press, 2008.
[17] Olowonmi Adekunle. The Writer and the Quest for Democratic Governance in Nigeria: Transcending PostIndependence Disillusionment. The Journal of Pan African Studies, vol. 2, no. 3, March 2008.

[18] Rau, Bill. From Feast to Famine: Official Cures and Grassroots Remedies to Africa's Food Crisis. London: Zed Books, 1991.

[19] Rodney, Walter. How Europe Underdeveloped Africa. Washington D. C.: Howard UP, 1982.

[20] Rogers, Jonna G. 'Aime Cesaire and his Poem "Out of Alien Days".' Feb.9,

2009.http://www.libarts.ucok.edu/English/faculty/stein/world2 /caribbean/electronic/aime_cesaire

[21] Soyinka, Wole. The Man Died: Prison Notes of Wole Soyinka. London: Africa Book Centre, 1972. 